\title{
Characterizing Bacteria and Methanogens in a Balloon-Type Digester Fed with Dairy Cattle Manure for Anaerobic Mono-Digestion
}

\author{
Christy Manyi-Loh ${ }^{1-3 *}$, Sampson Mamphweli ${ }^{1}$, Edson Meyer $^{1}$, Anthony Okoh ${ }^{2,3}$ \\ ${ }^{1}$ Fort Hare Institute of Technology, University of Fort Hare, Alice Campus, Alice, \\ Eastern Cape Province, South Africa \\ ${ }^{2}$ Applied and Environmental Microbiology Research Group (AEMREG), \\ Department of Biochemistry and Microbiology, University of Fort Hare, Alice Campus, \\ Alice, Eastern Cape Province, South Africa \\ ${ }^{3}$ South Africa Medical Research Council Microbial Water Quality Monitoring Centre, University of Fort Hare, \\ Alice, Eastern Cape Province, South Africa
}

Received: 14 June 2017

Accepted: 31 July 2017

\begin{abstract}
In this study, bacteria and methanogens involved in the decomposition of dairy cattle manure have been characterized via cultivation on selective microbiological media by the viable plate count technique. In addition, DNA was extracted from digested samples, and the 16S rRNA gene was amplified using six primer sets specific to bacterial and archaeal domain via PCR. The sequences of the PCR products were determined and compared to similar sequences in the GenBank database using the BLASTN tools to identify the closest relatives. By culture, E. coli, Salmonella, Shigella, and Campylobacter species were identified and belonged to the phylum Proteobacteria. Following, 16S rRNA analysis, Firmicutes $(80 \%)$ was the most dominant bacterial phylum represented by the predominant order Clostridiales and genus Clostridium. Other members belonged to the phyla Proteobacteria and Spirochaetes. The phylum Euryarchaeota $(100 \%)$ was the only observed archaeal domain with members that belonged to the dominant class Methanomicrobia and genus Methanocorpusculum. Other members were related to the order Methanobacteriales and Methanosarcinales. Results suggested that Clostridium sp, Clostridium related organisms, and other acidogens were responsible for the deconstruction of biomass-generating substrates metabolized by Methanocorpusculum and Methanobrevibacter species to produce methane via the fundamental hydrogenotrophic pathway.
\end{abstract}

Keywords: balloon digester, characterization, microorganisms, dairy cattle manure, South Africa

*e-mail: cmanyi-loh@ufh.ac.za 


\section{Introduction}

Across the globe, there is a tremendous rise in dairy farming operations owing to the high demand of dairy products for consumption [1]. However, these result in the generation of huge quantities of waste that calls for proper management, disposal, and or treatment in a bid to mitigate the numerous ruinous effects (environmental and public health hazards) associated with their improper release into the surroundings [2]. Anaerobic digestion technology has been applauded as an alternative treatment method of cattle manure since the process embodies waste sanitization, stabilization, biofertilizer production, and the recovery of renewable energy from the readily available substrate. It is a bioconversion process consisting of multi-step reactions responsible for the degradation of organic waste by four groups of metabolically linked microorganisms to produce methane and carbon dioxide [3]. Hydrolytic, acidogenic, and acetogenic bacteria along with methanogens are the key players acting at specific phases of the anaerobic digestion process and depend on each other for proper functioning.

Moreover, according to Uzodinma et al. [4], animal manure has been established as suitable substrates for anaerobic digestion as they harbour rumen microorganisms, which can facilitate the process. However, the level and types of these microorganisms in animal manure vary from one geographical location to the next due to differences in farm operations and depend on dietary sources, age, and species of the animals as well as the collection and storage principles existing in a farm [5,6]. More elaborately, environmental factors have an effect on the selection of microorganisms involved in a particular anaerobic digestion process, thus different processes harbour different microbial compositions [7]. However, just as the microbial size and quality in any natural ecosystem is being influenced by biotic and abiotic factors, clearly the microbial ecology that exists within a bioengineered ecosystem such as the biodigester is equally affected by substrate type, operational parameters, and the design of the digester as reported by several authors elsewhere [8-10].

Interestingly, South Africa is rich in plant biodiversity and the climatic and weather conditions vary across the provinces within the country. Seemingly, the variation in climatic and weather conditions as well as soil properties influence the vegetation/plant distribution in a particular geographical area [11]. This in turn affects the diet of animals on farms as well as the biological and physicochemical characteristics of the excreted manure. Precisely, the $\mathrm{pH}$ of excreted manure is related to the chemical composition of the animal's diet. This may suggest that the microbial composition of dung obtained from grazing animals might differ from that collected from stall-fed animals as well as from one country to another [12]. In addition, in the quest for the country's transition to a green economy, renewable energy and specifically a biodigester has been considered as one of the hubs for implementation [13]. Clearly, the choice of various organic wastes as renewable energy sources is an essential aspect of "green technologies" for biofuel production [14]. Numerous studies have analysed the diversity of microorganisms in biodigesters $[1,7,15]$; however, there are lucid differences in the microbial profiles existing in biodigesters fed with different types of biomass. This infers that the bacterial and archaeal profiles recovered from anaerobic digesters are specific to some degree for each biodigester/biomass type [16]. Surprisingly, to the best of our knowledge, there is a dearth of available information on the microorganisms (bacteria and methanogens) recovered from any biodigester planted in the Eastern Cape Province of the country.

Against this background, in this present work we have characterized the bacterial and archaeal microorganisms that coexisted in a balloon-type biodigester charged with dairy cattle manure for anaerobic decomposition to generate biogas. Culture and molecular-based techniques were employed, whereby easily cultivable bacteria were cultured using selective and enriched microbiological media. Secondly, DNA was extracted from several samples collected over an extended period of time, and the 16S r RNA gene of bacteria and methanogens were amplified using six different primer sets (i.e., three for bacteria and three for methanogens). The amplified products were purified and their sequences read and compared to similar sequences in the GenBank database.

\section{Materials and Methods}

\section{Study Site and Sample Collection}

Approximately $1700 \mathrm{~kg}$ of dairy cattle manure required to charge a balloon-type digester was obtained from the Fort Hare Dairy Trust in Alice, Eastern Cape Province, South Africa. The manure collected involved three samplings conducted over three successive days, during which portions were transferred into sterilized screw-capped bottles. The slurry was prepared after each day of collection and fed into the digester. The digester was batch-operated at mesophilic temperature and samples were collected every seven-day interval over a period of six (6) months at different positions of the digester for microbial analysis [17].

\section{Cultivation of Bacteria}

Each sample was withdrawn and introduced into the tryptone soy broth medium (Liofilchem Diagnostic, Italy) and transported on ice [18] to the Applied and Environmental Microbiology Research Laboratory, University of Fort Hare, Alice, and processed within 24 hours upon arrival at the laboratory. One gram of each sample was ten-fold serially diluted in $9 \mathrm{~mL}$ of sterile 
physiological saline. A hundred microlitres of each diluted sample (from $10^{-1}$ to $10^{-5}$ ) was spread on different selective microbiological media: Chromogenic E. coli agar (Conda, Spain), Salmonella/Shigella agar (Conda, Spain), and Blood Free Campylobacter agar (CCDA; Conda, Spain) for the isolation of E coli, Salmonellal Shigella, and Campylobacter species, respectively [17]. All inoculated plates were aerobically incubated at $37^{\circ} \mathrm{C}$ for $24-48$ hours, except the CCDA plates for the growth of Campylobacter species that were incubated at $42^{\circ} \mathrm{C}$ in a microaerophilic environment provided by a gas generating kit (BR0038, Oxoid, United Kingdom) for 48-72 hours. After incubation, distinct and isolated colonies were picked from the different media plates and subcultured for purity and subsequent identification.

Presumptive identification of these bacteria was based on growth on selective media, and cultural and morphological characteristics (gram staining) according to Cheesbrough [19]. Confirmation of the different bacteria isolates was based on biochemical tests, including catalase, oxidase, indole test, hippurate hydrolysis, hydrogen sulphide production, and sugar fermentation on triple sugar iron test, microaerobic growth at $42^{\circ} \mathrm{C}$, and susceptibility to Nalidixic acid [19].

\section{DNA Extraction from Digested Samples}

Twenty millilitres of sludge were transferred into sterile falcon tubes with screw-cap lids for DNA extraction. DNA was extracted from samples using ZR Soil Microbe DNA miniprep (Epigenetics, Zymo research, USA) as per the manufacturer's specifications and protocols. The concentration and purity of the extracted DNA were determined by examining its observance - both in 260 and $280 \mathrm{~nm}$. According to Sambrook and Russell [20], a pure DNA sample has the ratio of absorbance at 260 to absorbance at 280 recorded at 1.8 , while DNA samples contaminated with proteins often present with a ratio lower than 1.8. In addition, the integrity of the DNA was visually examined by agarose gel $(2 \% \mathrm{wt} / \mathrm{Vol})$ in $0.5 \mathrm{X}$ TAE, stained with ethidium bromide. The extracted, intact, and pure DNA was kept on $-20^{\circ} \mathrm{C}$ for further analysis.

\section{DNA Amplification by Polymerase Chain Reaction}

PCR amplification of the 16S rRNA gene of the bacterial and archaeal groups was carried out in a MyCycler thermal cycler (BIORAD). Summarily, the primer sets, conditions for PCR amplification, and visualization of PCR products areas shown in Table 1 . A suite of primer sets (IDT, White Sci, South Africa) was employed for the amplification of bacterial and archaeal 16S rRNA, which was performed in a total volume of $50 \mathrm{uL}$ with the PCR conditions stipulated as described elsewhere with slight modifications $[15,21-25]$. Each $50 \mathrm{uL}$ PCR reaction mixture consisted

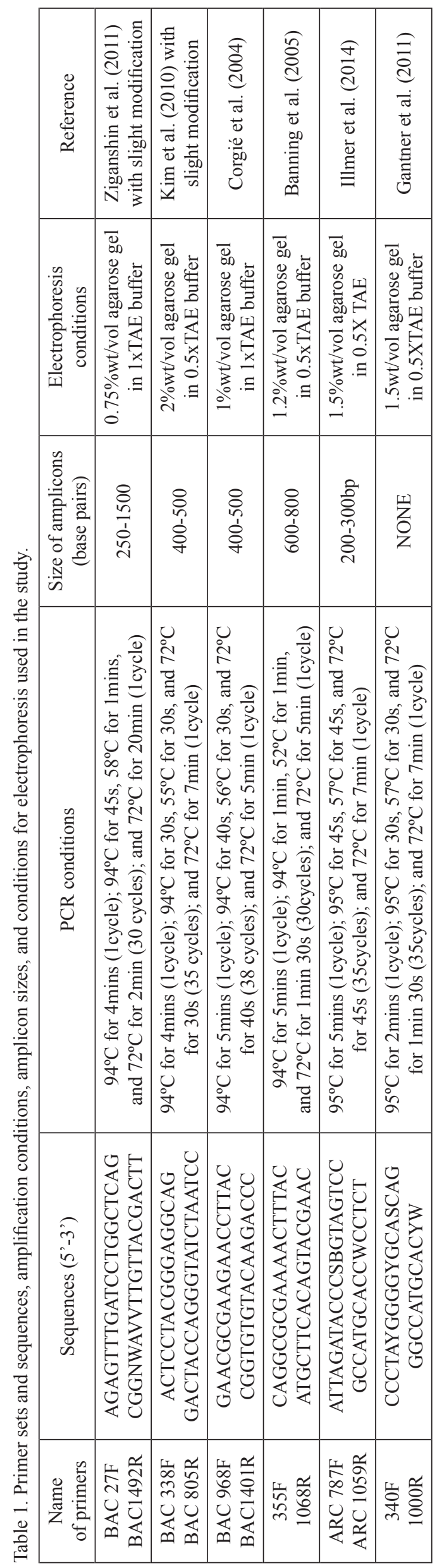


of $25 \mathrm{uL}$ Dream Taq Green PCR Master mix (Thermo Scientific), $5 \mathrm{uL}$ DNA template, $2.5 \mathrm{uL}$ of each primer, $2 \mathrm{uL}$ of bovine serum albumin (BSA, $10 \mathrm{mg} / \mathrm{mL}$ ), and $13 \mathrm{uL}$ of nuclease-free water. All PCR products (i.e., $5 \mathrm{uL}$ of amplicon) plus $1 \mathrm{uL}$ of DNA loading dye were validated and sized on agarose gel stained with ethidium bromide $(5 \mathrm{ug} / \mathrm{mL})$ and visualized under UV-light (Alliance 4.7). The Gene Ruler $1 \mathrm{~kb}$ DNA ladder (Thermo Scientific; ready to use 250-10,000 bp) was used as a molecular weight marker.

\section{Sequencing the Amplified Products}

Sequences were determined by electrophoresis with the ABI 3130xl DNA sequencer (Applied Biosystems, UK) based on established and validated protocols using a Big Dye Terminator DNA sequencing kit v3. 1 (Applied Biosystems, UK). Direct sequencing was done with $2 \mu \mathrm{L}$ of chromosomal DNA, $0.25 \mu \mathrm{L}$ of primer (10 pmol per $\mu \mathrm{L}), 2 \mu \mathrm{L}$ of Big 166 Dye buffer, and $2 \mu \mathrm{L}$ of Big Dye. Cycle parameters included a denaturation at $96^{\circ} \mathrm{C}$ for $10 \mathrm{~s}$, annealing at $50^{\circ} \mathrm{C}$ for $20 \mathrm{~s}$, and extension at $60^{\circ} \mathrm{C}$ for 4 min over 30 cycles, followed by Agencourt CleanSeq clean-up. The resulting chromatograms were viewed and the derived sequences were edited using BioEdit Alignment Editor Software [26]. The cleaned nucleotide sequences were identified by using the BLASTN tools (ncbi.nlm.nih.gov/BLAST) [26] to search for similar sequences of the reference organisms in the GenBank (NCBI) database [27].

\section{Results and Discussion}

The biodiversity of microbes within a biodigester is of great significance owing to the large contribution of microbial interactions in the production of biogas - a renewable energy and a stabilized digestate (biofertilizer). Consequently, the census of the organisms relevant in the eminent anaerobic digestion process should not be precluded. However, culturedependent techniques employed in the characterization of these diverse microbial populations relied only on the identification/enumeration of facultative anaerobes/ aerobes that are easily cultivable in vitro, whereas the dominating population consisting of strict anaerobes are underestimated due to their fastidious nature, thus failing to grow in normal growth conditions [28]. In addition, the methanogens are categorized among the most difficult organisms to cultivate in vitro due to the fact that they are fastidious, with a slow-growing tendency and the need for strict anaerobic conditions for growth [29]. Interestingly, the development of cultureindependent methods targeting the $16 \mathrm{~S}$ rRNA gene (a small universal gene of approximately 1,500 bp, with highly conserved and hypervariable regions, V1-V9) via the polymerase chain reaction has greatly improved the attempt to analyse the microbial ecology within the digester [30].
During this investigation, the culture-based and the 16S rRNA-PCR-based methods were employed to characterize the microbial population involved in the batch fermentation of dairy cattle manure in a balloon-type digester. Following cultivation on the selective microbiological media, the distinct, isolated, and presumptive identified colonies were confirmed by biochemical characterization to be E. coli, Campylobacter sp, Salmonella sp, Shigella sp, and Proteus sp. These entire organisms that were recovered belonged to the phylum Proteobacteria; however, they were found only during the early days of decomposition and were decimated as the process progressed. Exceptionally, Salmonella organisms took a longer time for decimation and these findings have been elaborated upon in our published data [31]. Apparently, Wirth et al. [32] documented the relevance to the biomass deconstruction of the members of the phylum Proteobacteria during anaerobic digestion.

Owing to the enormous population of microbes that normally reside in the gastrointestinal tract of cattle and via excretion, they eventually end up in cattle manure; several samples were collected from different sites in the biodigester as well as six primer sets spanning more than one hypervariable region of the 16S rRNA gene, which was utilized for amplification in order to positively augment the sensitivity, specificity, and reliability of the molecular methodology [33].

Overall, the 16S rRNA gene sequence analysis represented known bacterial (30) and archaeal (74) microorganisms that were characterized from the anaerobic mono-digestion of dairy cattle manure in a balloon-type digester. Furthermore, the analysis of bacterial nucleotide sequences recovered organisms that belonged to the phyla Firmicutes, Spirochaetes, and Proteobacteria. Generally, members of the phyla Firmicutes and Proteobacteria have been reported to be widely distributed both in natural and bioengineered habitat and are responsible for the efficient degradation of complex organic matter, including cellulose, lignin, chitin, etc. [34]. These acidogenic bacteria play a primary role in producing major substrates such as hydrogen, carbon dioxide, formate, acetate, and shortchain organic acids for methanogenesis [23]. The most dominant phylum was Firmicutes (88\%) represented by the classes Clostridia and Bacilli, but the class Clostridia (84\%) was the most prominent between these two. This finding corroborates the studies of Regueiro and co-authors [35], Moset et al. [36], and Levén and colleagues [7], who equally observed a dominance of the phylum Firmicutes and Class Clostridia in other community analyses of microorganisms in bioreactors. Nevertheless, the predominant class Clostridia might have comprised of cellulolytic, proteolytic, and homoacetogenic Clostridium species responsible for decomposing polymers to monomers as well as performing the first step in syntrophic acetate oxidation to methane, respectively $[37,38]$. 
Although the class Clostridia (84\%) was hereby highly represented by the genus Clostridium (approximately 34\%), all the members of this class belonged to the following families Clostridiaceaea (34\%), Ruminococcaceae (6\%), Peptostreptococcaceae (22\%), Lachnospiraceae (6\%), and Eubacteriaceae $(13 \%)$. However, other bacterial sequences were grouped into the families Pseudomonadaceae (3\%), Leptospiraceae (3\%), and Paenibacillaceae (3\%). Overall, taking into consideration the aforementioned families, the specific members belonging to the following genera: Clostridium, Ruminococcus, Brevibacillus, Romboutsia, Leptospira, Pseudomonas, Intestinimonas, Roseburia, Lachnoclostridium, and Eubacterium were identified within the phylum Firmicutes.

On the other hand, all the archaeal 16S rRNA gene sequences were related to sequences of known archaeal species. Wholly, the methanogens belonged to the phylum Euryarchaeota (100\%) and the genus Methanocorposculum belonging to the class Methanomicrobia (approx. 64\%) had the highest occurrence. Clearly, the major part of the phylum Euryarchaeota belonged to the genera Methanocorpusculum (order Methanomicrobiales) and Methanobrevibacter (order Methanobacteriales) representing the classes Methanomicrobia and Methanobacteria, respectively. These results were strongly consistent with the findings of several authors, who reported Methanomicrobiales and Methanobacteriales as the dominant orders in anaerobic reactors treating animal wastes $[1,39$, 40]. In addition, methanogens categorized into these orders Methanomicrobiales and Methanobacteriales have been noted to utilize $\mathrm{H}_{2} / \mathrm{CO}_{2}$ or formate for methane production, and are thus described as hydrogenotrophic methanogens. This may suggest that from the physiological perspective, hydrogenotrophic methanogenesis dominated the methane-yielding process [41]. Moreover, Methanobrevibacter and Methanocorpusculm species are well known species that occur in the animal's rumen and are pivotal in methane production in the environmental milieu subjected to seasonal variations in temperature [1].

However, all the identified archaeal sequences belonged to the families Methanocorpusculaceae (54\%), Methanobacteriaceae (36.5\%), and Methanosarcinaceae $(8.5 \%)$. Notwithstanding, other members belonged to the family Methanomicrobiaceae (1.4\%), which was the least represented notably by the genus Methanoculleus. Among the methanogens, the members belonging to the genus Methanosarcina, order Methanosarcinales were equally observed. Members of this genus are metabolically diverse with respect to their substrate utilization to methane production. They are capable of utilizing a range of substrates including both hydrogen and acetate. Thus, they could be described as acetoclastic methanogens [22]. This further indicated that the acetoclastic methanogenesis pathway was also implemented for the production of methane in this study.
According to De Vrieze and colleagues [42], the acetoclastic methanogenesis pathway should be more favourable as oppose to the hydrogenotrophic methanogenesis in an anaerobic reactor on the basis of the energy involved. In this light, the establishment of the syntrophic relationship between members of the genus Methanosarcina and homoacetogenic bacterium (class Clostridia) could further increase methane production. The archaeal and bacterial sequences delineated in this study presented with high similarity to uncultured strains and known species already characterized from several natural and bioengineered habitats studied in different parts of the world. Consequently, the microbial community elucidated herein seemed to be representative of a biomass-degrading microbial consortia [1].

\section{Conclusions}

On the whole, these results revealed the first insight into the assemblage of functional microorganisms engaged in the batch mono-digestion of dairy cattle manure procured from the Fort Hare Dairy Trust, Alice, Eastern Cape Province of South Africa. These findings substantiate the possibility of effective anaerobic degradation of dairy wastes through the concerted activities of bacterial communities that belonged to the phyla Firmicutes, Spirochaetes, and Proteobacteria, and archaeal communities that belonged to a single phylum, Euryarchaeota, represented by the classes Methanomicrobia and Methanobacteria. In addition, it has been demonstrated that Clostridium species were the most prevalent bacteria, and together with other Clostridium-related organisms were suggested to be involved in cellulolysis, proteolysis, acidogenesis, and homoacetogenesis. The genus Methanocorpusculum was the dominant archaeal member in the anaerobic breakdown process, followed by Methanobrevibacter. The high prevalence of these genera unravelled their essential role in the methanogenesis phase. As a result, it may suggest that hydrogenotrophic methanogenesis was the more prominent route to yield methane from the metabolism of $\mathrm{H}_{2} / \mathrm{CO}_{2}$ or formate, since Methanocorpusculum and Methanobrevibacter strains harbour genomes endowed with significant genes responsible for the utilization of $\mathrm{CO}_{2}, \mathrm{H}_{2}$, and formate during methanogenesis. However, it is worth mentioning that these findings achieved via batch operation may not be a representative for anaerobic treatment of dairy wastes in a continuous operation, but the results could serve as valuable information needed to set up a continuous operation.

Overall, in the digester, most of the bacterial and archaeal species were uncultured. Further studies are hereby needed to explicate the taxonomic characterization of the uncultured bacteria, which showed no distinct similarity to any identified cultured and uncultured bacteria. Also, an in-depth look 
at the microbial structure and their roles performed in such a complex ecosystem is envisaged for better understanding the population dynamics with respect to metabolism.

\section{Acknowledgements}

We are grateful to Claude Leon and the National Research Foundations (grant No. 98031), Department of Science and Technology, South Africa for financial support. Also to the South Africa Medical Research Council for financial support via available equipment. Special thanks also to the Institute of Technology and Govan Mbeki Research and Development Centre, University of Fort Hare, for the purchase of materials and consumables employed in this study.

\section{Conflict of Interest}

The authors declare no conflict of interest.

\section{References}

1. RESENDE J.A., GODON J-Q., BONNAFOUS A., ARCURI P.B., SILVA V.L., OTENIO M.H., DINIZ C.G. Seasonal variation on microbial community and methane production during anaerobic digestion of cattle manure in Brazil. Microbial Ecology, 71, 735, 2016.

2. GERBA C.P., SMITH J.E. JR. Sources of pathogenic microorganisms and their fate during land application of wastes. Journal of Environmental Quality, 34, 42, 2005.

3. LOZANO C.J.S, MENDOZA M.V., MARIELA CARRENO DE ARANGO M.C., MONROY E.F.C. Microbiological characterization and specific methanogenic activity of anaerobe sludges used in urban solid waste treatment. Waste Management, 29, 704, 2009.

4. UZODINMA E.O., OFOEFULE A.E., EZE J.I., MBAEYI I., ONWUKA N.D. Effect of some organic wastes on the biogas yield from carbonated soft drink sludge. Scientific Research and Essays, 3, 401, 2008.

5. HUTCHISON M.L., WALTERS L.D., AVERY S.M., MUNRO F., MOORE A. Analyses of livestock production, waste storage and pathogen levels and prevalences in farm manures. Applied and Environmental Microbiology, 71, 1231, 2005.

6. SPIEHS M., GOYAL S. Best Management practices for Pathogen Control in Manure Management Systems; University of Minnesota Extension: St. Paul, MN, USA, 2007; M1211.

7. LEVÉN L., ERIKSSON A.R.B., SCHNÜRER A. Effect of process temperature on bacterial and archaeal communities in two methanogenic bioreactors treating organic household waste. FEMS Microbiology Ecology, 59, 683, 2007.

8. CHEN Y., CHENG J.J., CREAMER K.S. Inhibition of anaerobic digestion process: a review. Bioresource Technology, 99, 4044, 2008.

9. CIOABLA A.E., LONEL L., DUMITREL G.A., POPESCU F. Comparative study on factors affecting anaerobic digestion of agricultural vegetal residues. Biotechnology for Biofuels, 5, 39, 2012.

10. FACCHIN V., CAVINATO C., FATONE F., PAVAN P., CECCHI F., BOLZONELLA D. Effect of trace elements supplementation on the mesophilic anaerobic digestion of food wastes in batch trials: the influence of inoculum origin. Biochemical Engineering Journal, 70, 71, 2013.

11. CASTRO-VÁRQUEZ L., DÍAZ-MAROTO M.C., DE TORRES C., PÉREZ-COELLO M.S. Effect of geographical origin on the chemical and sensory characteristics of chestnut honeys. Food Research International, 43 (10), 2335, 2010.

12. SAKAR S., YETILMEZSOY K., KOCAK E. Anaerobic digestion technology in poultry and livestock waste treatment. Waste Management and Research, 27, 3, 2009.

13. ACADEMY OF SCIENCE OF SOUTH AFRICA. The state of green technologies in South Africa. Academic of Science of South Africa (ASSAf), Pretoria, South Africa, 92, 2014.

14. ANTONI D., ZVERLOV V.V., SCHWARZ W.H. Biofuels from microbes. Applied Microbiology and Biotechnology. 77, 23, 2007.

15. ZIGANSHIN A.M., SCHMIDT T., SCHOLWIN F., II'INSKAYA O.N., HARMS H., KLEINSTEUBER S. Bacteria and archaea involved in anaerobic digestion of distillers grains with soluble. Applied Microbiology and Biotechnology, 89, 2039, 2011.

16. ABENDROTH C., VILANOVA C., GÜNTHER T., LUSCHNIG O., PORCAR M. Eubacteria and archaea communities in seven mesophilic anaerobic digester plants in Germany. Biotechnology for Biofuels, 8, 87, 2015.

17. POUDEL R.M., JOSHI D.R., DHAKAL N.R., KARKI A.B. Anaerobic digestion of sewage sludge mixture for the reduction of indicator and pathogenic microorganisms. Scientific World, 8, 47, 2010.

18. THAKER H.C., BRAHMBHATT M.N., NAYAK J.B. Study on occurrence and antibiogram pattern of Escherichia coli from raw milk samples in Anand, Gujarat, India. Veterinary World, 5 (9), 556, 2012.

19. CHEESBROUGH M. District Laboratory Practice in Tropical Country, Part 2: Microbiology. Cambridge, UK: Cambridge University Press, 2000.

20. SAMBROOK J., RUSSELL D.W. Molecular cloning- A Laboratory Manual, Cold Spring Harbor Laboratory Press, Cold Spring Harbor, New York, USA, 2001.

21. CORGIÉ S.C., BEGUIRISTAIN T., LEYVAL C. Spatial distribution of bacterial communities and phenanthrene degradation in the rhizosphere of Lolium perenne L. Applied and Environmental Microbiology, 70 (6), 3552, 2004.

22. BANNING N., BROCK F., FRY J.C., PARKES R.J., HORNIBROOK E.R.C., WEIGHTMAN A.J. Investigation of the methanogen population structure and activity in a brackish lake sediment. Environmental Microbiology. 7 (7), 947, 2005.

23. KIM W., HWANG K., SHIN S.G., LEE S., HWANG S. Effect of high temperature on bacterial community dynamics in anaerobic acidogenesis using mesophilic sludge inoculum. Bioresource Technology, 101, S17-S22, 2010.

24. GANTNER S., ANDERSSON A.F., ALONSO-SÁEZ L., BERTILSSON S. Novel primers for 16S rRNA-based archaeal community analyses in environmental samples. Journal of Microbiological methods, 84, 12, 2011.

25. ILLMER P., REITSCHULER C., WAGNER A.O., SCHWARZENAUER T., LINS P. Microbial succession 
during thermophilic digestion: The potential of Methanosarcina sp. PLOSONE, 9 (2), e86967, 2014.

26. HALL T.A. BioEdit: a user-friendly biological sequence alignment, editor and analysis program for Windows 95/98/NT. Nucleic Acids Symposium Ser 41, 95, 1999.

27. ALTSCHUL S.F., GISH W., MILLER W., MYERS E.W., LIPMAN D.J. Basic local alignments search tool. Journal of Molecular Biology, 215, 403, 1990.

28. GIRIJA D., DEEPA K., XAVIER F., ANTONY I., SHIDHI P.R. Analysis of cow dung microbiota-A metagenomic approach. Indian Journal of Biotechnology, 12, 372, 2013.

29. GROSSKOPF R., JANSSEN P.H., LIESACK W. Diversity and structure of the methanogenic community in anoxic rice paddy soil microcosms as examined by cultivation and direct 16S rRNA gene sequence retrieval. Applied and Environmental Microbiology, 64, 960, 1998.

30. WANG Y., QIAN P-Y. Conservative fragments in bacterial 16S rRNA genes and primer design for 16S ribosomal DNA amplicons in metagenomic studies. PLoS ONE, 4 (10), e7401, 2009.

31. MANYI-LOH C.E., MAMPHWELI S.N., MEYER E.L., OKOH A.I., MAKAKA G., SIMON M. Inactivation of selected bacterial pathogens in dairy cattle manure by mesophilic anaerobic digestion (balloon type digester). International Journal of Environmental Research and Public Health, 11, 7184, 2014.

32. WIRTH R., KOVÁCA E., MARÓTI G., BAGI Z., RAKHELY G., KOVÁCS K.L. Characterization of a biogas-producing microbial community by short-read next generation DNA sequencing. Biotechnology for Biofuels, 5, 41, 2012.

33. PITERINA A.V., BARTLETT J., PEMBROKE J.T. Molecular analysis of bacterial community DNA in sludge undergoing autothermal thermophilic aerobic digestion (ATAD): pitfalls and improved methodology to enhance diversity recovery. Diversity, 2, 505, 2010.

34. BERNARDET J.F., BOWMAN J.P. The genus Flavobacterium. The Prokaryotes: An Evolving Electronic Resource for the Microbiological Community, $3^{\text {rd }} \mathrm{sdn}$ (Dworkin, M, ed), http://link.springer-ny.com/link/service/ books/10125).Springer-Verlag, New York, USA, 2003.
35. REGUEIRO L., VEIGA P., FIGUEROA M., ALONSOGUTIERREZ J., STAMS A.J.M., LEMA J.M., CARBALLA M. Relationship between microbial activity and microbial community structure in six full-scale anaerobic digesters. Microbiological Research, 167, 581589, 2012.

36. MOSET V., POULSEN M., WAHID R., HФJBERG O., MФLLER H.B. Mesophilic versus thermophilic anaerobic digestion of cattle manure: methane productivity and microbial ecology. Microbial Biotechnology, 8 (5), 787, 2015.

37. LIU F.H., WANG S.B., ZHANG J.S., ZHANG J., YAN X., ZHOU H.K., ZHAO G.P., ZHOU Z.H. The structure of the bacterial and archaeal community in a biogas digester as revealed by denaturing gradient gel electrophoresis and $16 \mathrm{~S}$ rDNA sequencing analysis. Journal of Applied Microbiology, 106, 952, 2009.

38. WALTER A., KNAPP B.A., FARBMACHER T., ENBER C., INSAM H., FRANKE-WHITTLE I.H. Searching for links in the biotic characteristics and abiotic parameters of nine different biogas plants. Microbial Biotechnology $\mathbf{5}$, 717, 2012.

39. SONG M., SHIN S.G. HWANG S. Methanogenic population dynamics assessed by real-time quantitative PCR in sludge granule in up flow anaerobic sludge blanket treating swine waste water. Bioresource Technology, 101, 523, 2010.

40. MOSET V., BERTOLINI E., CERISUELO A., CAMBRA M., OLMOS A., CAMBRA LÓPEZ M. Start-up strategies for thermophilic anaerobic digestion of pig slurry. Energy, 74, 389, 2014.

41. ANDERSON I.J., SIEPRAWSKA-LUPA M., GOLTSMAN E., LAPIDUS A., COPELAND A., DEL RIO T.G., TICE H., DALIN E., BARRY K., PITLUCK S., HAUSER L., LAND M., LUCAS S., RICHARDSON P. WHITMAN W.B., KYRPIDES N.C. Complete genome sequence of Methanocorpusculum labreanum type strain Z. Standards in Genomic Sciences 1, 197, 2009.

42. DE VRIEZE J., HENNEBEL T., BOON N., VERSTRAETE W. Methanosarcina: the rediscovered methanogen for heavy duty biomethanation. Bioresource Technology, 112, 1, 2012. 
